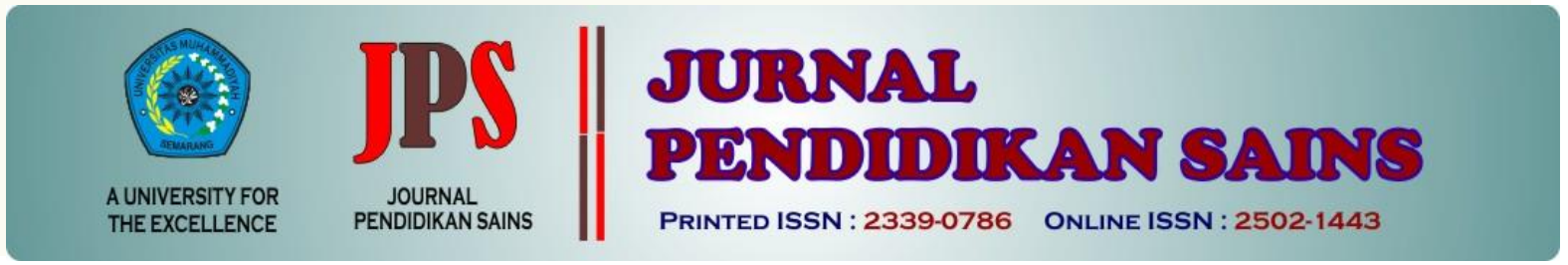

http://jurnal.unimus.ac.id/index.php/JPKIMIA

\title{
ANALISIS MISKONSEPSI ASAM BASA CALON GURU KIMIA DENGAN METODE THREE-TIER TEST
}

\author{
Oleh: Abdullah*, Rini, Ardiansyah \\ Fakultas Keguruan dan Ilmu Pendidikan Universitas Riau
}

\begin{tabular}{|c|c|}
\hline Article history & \\
\hline : 2019-08-12 & \multirow{5}{*}{$\begin{array}{l}\text { This study aims to identify the misconceptions of prospective chemistry } \\
\text { teacher. The study population was all students of the Chemistry Study } \\
\text { Program at the University of Riau, while the sample was } 66 \text { students } \\
\text { at the Chemistry Study Program at the University of Riau, selected by } \\
\text { cluster random sampling technique. Conception data of chemistry } \\
\text { teacher candidates on acid-base subjects have been identified and } \\
\text { obtained by providing valid acid-base TTT diagnostic tests to } \\
\text { chemistry teachers candidates. The result of this research showed that } \\
\text { chemistry teacher candidate who experienced misconception on acid } \\
\text { base subject were } 66.5 \% \text { from } 4 \text { main concepts studied, namely acid } \\
\text { and base concepts (51.15\%), pH and pOH concepts and their } \\
\text { calculations (79.06\%), the concept of acid-base dissociation degree } \\
\text { (75.43\%), and the concept of acid-base titration and indicator } \\
\text { (58.13\%). The study also revealed that some students have difficulties } \\
\text { in performing mathematical operations using logarithms. }\end{array}$} \\
\hline 20 & \\
\hline : 2020-03-31 & \\
\hline Keyword: & \\
\hline miskonsepsi & \\
\hline
\end{tabular}

\section{Pendahuluan}

Guru memegang peran yang sangat vital dalam menjamin kualitas pendidikan. Pendidikan yang baik akan terwujud jika guru yang menjalankan tugasnya telah memenuhi kompetensi profesional, pedagogik, kepribadian, dan sosial (Noviartati, 2015:57). Kompetensi profesional guru diperoleh di bangku kuliah dan dikembangkan setelah mereka menjadi guru (Supartini, 2003:66). Di Indonesia, guru dihasilkan oleh Lembaga Pendidikan dan Tenaga Kependidikan (LPTK). Lembaga ini bertanggung jawab terhadap pendidikan calon guru dan kualitas guru yang dihasilkan. Universitas Riau (UR) merupakan salah satu LPTK di Indonesia yang menghasilkan lulusan guru kimia melalui Program Studi Pendidikan Kimia. Calon guru kimia haruslah memiliki pengetahuan yang benar tentang bidang studi kimia.

Kimia merupakan ilmu yang mempelajari komposisi, sifat, dan perubahan materi (Jespersen, dkk., 2012:2). Selain itu, ilmu kimia juga dikenal dengan ilmu yang sebagian besar konsepnya bersifat abstrak. Hal ini menyebabkan ilmu kimia sulit dipelajari oleh mahasiswa (Wulandari, dkk., 2018:167) dan dapat memicu terjadinya kesalahan konsep (miskonsepsi). Miskonsepsi merupakan konsep yang dimiliki seseorang yang berbeda dengan konsep sebenarnya menurut para ahli (Ikenna, 2014:3259).

Salah satu pokok bahasan kimia yang sarat akan konsep adalah pokok bahasan asam basa. Konsep dasar pokok bahasan asam basa meliputi konsep asam basa menurut para ahli, reaksi asam basa, perhitungan $\mathrm{pH}$, indikator,

\footnotetext{
*Corresponding Author:

Nama : Abdullah

Lembaga : FKIP Universitas Riau

Email : abdoel71@gmail.com
} 
dan titrasi asam basa yang merupakan pokok bahasan penting dalam ilmu kimia. Asam basa merupakan konsep kunci dalam ilmu kimia karena berbagai bahasan dalam ilmu kimia sangat bergantung pada pemahaman tentang konsep asam basa. Namun, konsep asam basa sebagian bersifat abstrak sehingga kemungkinan terjadinya miskonsepsi calon guru kimia sangat besar.

Miskonsepsi yang terjadi akan menyulitkan calon guru kimia untuk mempelajari konsep selanjutnya. Karena tidak mungkin mereka dapat mempelajari konsep yang lebih tinggi jika konsep dasarnya tidak sesuai dengan para ahli. Penelitian identifikasi miskonsepsi pernah dilakukan oleh Yulita (2018:64-72) pada konsep hakikat ilmu kimia dan menyatakan penelitian identifikasi miskonsepsi sangat penting dilakukan untuk mengetahui miskonsepsi peserta didik. Identifikasi konsepsi mahasiswa calon guru kimia sangat diperlukan untuk membantu mereka menguasai konsep dengan benar dan mencegah terjadinya miskonsepsi lebih lanjut. Miskonsepsi yang terjadi dapat diidentifikasi dengan menggunakan berbagai metode yang ada, diantaranya dengan petakonsep, tes pilihan ganda dengan alasan terbuka (two-tier test), tes esai, wawancara, diskusi, praktikum, dan tanya jawab (Suparno, 2013:129).

Kelebihan two-tier test dibandingkan metode yang ada adalah metode ini lebih efektif, mudah diterapkan, tidak subjektif, dan hasilnya lebih valid untuk menemukan miskonsepsi (Akkus, dkk., 2011). Namun, kelemahan metode ini adalah tidak bisa membedakan siswa yang tidak tahu konsep dengan siswa yang menebak jawaban. Oleh karena itu, metode two-tier test digabungkan dengan Certainty of Response Index (CRI) (Hasan, dkk., 1999) menghasilkan metode baru, yaitu three tier-test (TTT).

TTT terdiri dari 3 tingkatan pertanyaan. Tingkat pertama merupakan bagian pernyataan, dan bagian kedua merupakan pilihan alasan untuk pernyataan pertama. Sedangkan tingkat ketiga adalah CRI yang membedakan calon guru yang yakin, tidak yakin, dan ragu-ragu dalam menjawab soal (Pesman, 2005). TTT diharapkan mampu membedakan calon guru yang menebak dengan yang tidak tahu konsep.

Irwansyah dan kolega (2018:207) telah berhasil mengembangkan instrumen TTT konsep fluida yang dapat membedakan siswa yang tahu konsep dengan siswa yang mengalami miskonsepsi. Sedangkan
Resbiantoro dan Nugraha (2017:186) telah melakukan penelitian miskonsepsi tentang konsep dasar gaya dan gerak pada calon guru sekolah dasar di Tulungagung dengan menggunakan CRI sebagai bagian dari tes beberapa tingkat yang digunakan untuk membedakan calon guru yang miskonsepsi, menebak, dan kurang pengetahuan. Sadhu dan kolega (2017:93) juga menggunakan tes CRI dan wawancara untuk mengidentifikasi miskonsepsi pada konsep asam basa pada siswa SMA dengan berbagai tingkatan kognitif.

$$
\text { Penelitian ini bertujuan }
$$
mengembangkan instrumen TTT asam basa yang valid untuk mengidentifikasi konsepsi pada mahasiswa calon guru kimia pada pokok bahasan asam basa.

\section{Metode Penelitian}

Penelitian ini merupakan penelitian deskriptif. Pemilihan sampel mahasiswa calon guru kimia dilakukan dengan teknik cluster random sampling. Instrumen yang digunakan adalah 15 item soal TTT asam basa yang telah divalidasi oleh validator ahli. Selain itu, juga dilakukan wawancara terhadap beberapa mahasiswa calon guru kimia yang mengalami miskonsepsi.

Berdasarkan hasil tes miskonsepsi, sampel dikelompokkan kedalam empat kategori, yaitu mahasiswa yang tahu konsep, tidak tahu konsep, menebak dan yang mengalami miskonsepsi (Tabel 1) (Kurniawan dan Suhandi, 2015).

Tabel 1. Kriteria pengelompokan konsepsi

\begin{tabular}{cccc}
\hline Tingkat 1 & Tingkat 2 & $\begin{array}{c}\text { Tingkat 3 } \\
\text { (CRI) }\end{array}$ & Keputusan \\
\hline Benar & Benar & Yakin & Tahu Konsep \\
\hline Benar & Benar & Tidak Yakin & Menebak \\
\hline Benar & Salah & Yakin & Miskonsepsi \\
\hline Benar & Salah & Tidak Yakin & Menebak \\
\hline Salah & Salah & Yakin & Miskonsepsi \\
\hline Salah & Salah & Tidak Yakin & $\begin{array}{c}\text { Tidak Tahu } \\
\text { Konsep }\end{array}$ \\
\hline Salah & Benar & Yakin & Miskonsepsi \\
\hline Salah & Benar & Tidak Yakin & Menebak \\
\hline
\end{tabular}

Konsep yang dianalisis miskonsepsinya dibagi menjadi 4 konsep utama yang tersebar melalui 15 soal TTT asam basa sebagai berikut :

1. Mengidentifikasi asam dan basa serta reaksinya (soal nomor 1, 2, 3 dan 9).

2. Menjelaskan konsep $\mathrm{pH}, \mathrm{pOH}$ serta perhitungannya (soal 4 sampai 8).

3. Menjelaskan konsep derajat disosiasi asam basa (soal nomor 10-12)

4. Menjelaskan konsep titrasi asam basa dan indikatornya (soal nomor 13-15) 


\section{Hasil Penelitian dan Pembahasan}

Berdasarkan jawaban mahasiswa calon guru kimia terhadap soal TTT asam basa yang diberikan (Tabel 2), maka konsepsi mahasiswa dikelompokkan menjadi 4 kelompok seperti pada Tabel 3.

Berdasarkan Tabel 3 dapat dilihat bahwa rata-rata persentase miskonsepsi semua konsep adalah $66,5 \%$. Rata-rata persentase miskonsepsi tertinggi untuk tiap konsep terjadi pada konsep pH larutan, yaitu sebesar 79,06\%, sedangkan yang terendah terjadi pada konsep reaksi asam basa, yaitu sebesar 51,2\%.

Tingginya persentase miskonsepsi pada konsep $\mathrm{pH}$ larutan disebabkan oleh hampir semua mahasiswa calon guru kimia mengalami miskonsepsi pada konsep $\mathrm{pH}$ netral (soal nomor 4) dan konsep skala $\mathrm{pH}$ (soal nomor 8). Miskonsepsi terendah terjadi pada soal nomor 3, yaitu sebesar $26,2 \%$, sedangkan miskonsepsi tertinggi terjadi pada soal nomor 8 dan 10 , yaitu sebesar $92,9 \%$.

Tabel 2. Distribusi jawaban mahasiswa calon guru kimia

\begin{tabular}{|c|c|c|c|c|c|c|c|c|c|c|c|}
\hline \multirow{2}{*}{$\begin{array}{l}\text { No. } \\
\text { soal }\end{array}$} & \multicolumn{5}{|c|}{ Tingkat I } & \multicolumn{5}{|c|}{ Tingkat II } & \multirow{2}{*}{$\begin{array}{c}\text { III } \\
\text { (CRI) }\end{array}$} \\
\hline & $\mathbf{A}$ & B & C & D & $\mathbf{E}$ & $\mathbf{A}$ & B & C & D & $\mathbf{E}$ & \\
\hline 1 & 9,5 & 2,4 & 31,0 & $50,0^{*}$ & 2,4 & 7,1 & 14,3 & 4,8 & $59,5^{*}$ & 9,5 & 3,66 \\
\hline 2 & 4,8 & 2,4 & $83,3^{*}$ & 9,5 & 0,0 & 2,4 & $45,2 *$ & 52,4 & 0,0 & 0,0 & 3,64 \\
\hline 3 & 0,0 & 9,5 & $69,0^{*}$ & 11,9 & 9,5 & 7,1 & 14,3 & $66,7 *$ & 9,5 & 2,4 & 3,40 \\
\hline 4 & 97,6 & $2,4^{*}$ & & & & 54,8 & $0,0^{*}$ & 0,0 & 42,9 & 0,0 & 3,56 \\
\hline 5 & $7,1 *$ & 90,5 & & & & 16,7 & $9,5^{*}$ & 57,1 & 11,9 & 2,4 & 3,48 \\
\hline 6 & 26,2 & 71,4* & & & & 31,0 & 14,3 & 9,5 & $7,1 *$ & 33,3 & 3,2 \\
\hline 7 & 59,5 & $40,5^{*}$ & & & & 57,1 & 26,2 & $11,9^{*}$ & 0,0 & 4,8 & 3,45 \\
\hline 8 & 95,2 & $4,8^{*}$ & 0,0 & 0,0 & & 76,2 & 2,4 & 2,4 & $4,8^{*}$ & 11,9 & 3,42 \\
\hline 9 & 76,2 & $19,0^{*}$ & & & & $\begin{array}{l}54,8 \\
\end{array}$ & 14,3 & 2,4 & $4,8 *$ & 19,0 & 3,43 \\
\hline 10 & 95,2 & $4,8^{*}$ & & & & 16,7 & 50,0 & $4,8^{*}$ & 28,6 & 0,0 & 3,45 \\
\hline 11 & 73,8 & $21,4^{*}$ & & & & 59,5 & $19,0^{*}$ & 16,7 & 0,0 & 0,0 & 2,89 \\
\hline 12 & 73,8 & $26,2^{*}$ & & & & 61,9 & 11,9 & 23,8 & $0,0^{*}$ & 2,4 & 3,44 \\
\hline 13 & 9,5 & $88,1^{*}$ & & & & 4,8 & 4,8 & 0,0 & 52,4 & $33,3^{*}$ & 3,27 \\
\hline 14 & 4,8 & $92,9 *$ & & & & 0,0 & 0,0 & 0,0 & 47,6 & $50,0^{*}$ & 3,53 \\
\hline 15 & 69,0 & $28,6^{*}$ & & & & 59,5 & 11,9 & 2,4 & $14,3^{*}$ & 9,5 & 3,08 \\
\hline
\end{tabular}

*kunci jawaban

Tabel 3. Persentase konsepsi mahasiswa calon guru kimia

\begin{tabular}{|c|c|c|c|c|c|c|}
\hline \multirow{2}{*}{ No } & \multirow{2}{*}{ Konsep Utama } & \multirow{2}{*}{$\begin{array}{c}\text { No. } \\
\text { Soal } \\
\end{array}$} & \multicolumn{4}{|c|}{ Persentase Konsepsi } \\
\hline & & & MK & TK & MB & TTK \\
\hline \multirow{4}{*}{ I } & \multirow{4}{*}{ Reaksi asam basa } & 1 & 42,9 & 42,9 & 2,4 & 11,9 \\
\hline & & 2 & 52,4 & 40,5 & 2,4 & 4,8 \\
\hline & & 3 & 26,2 & 54,8 & 9,5 & 9,5 \\
\hline & & 9 & 83,3 & 4,8 & 2,4 & 9,5 \\
\hline & Rata-rata konsep I & & 51,2 & 35,72 & 4,18 & 8,9 \\
\hline \multirow{5}{*}{ II } & \multirow{5}{*}{$\mathrm{pH}$ larutan } & 4 & 88,1 & 0,0 & 2,4 & 9,5 \\
\hline & & 5 & 64,3 & 7,1 & 0,0 & 28,6 \\
\hline & & 6 & 66,7 & 2,4 & 21,4 & 9,5 \\
\hline & & 7 & 83,3 & 11,9 & 2,4 & 2,4 \\
\hline & & 8 & 92,9 & 4,8 & 0,0 & 2,4 \\
\hline \multicolumn{3}{|c|}{ Rata-rata konsep II } & 79,06 & 5,24 & 5,24 & 10,48 \\
\hline \multirow{3}{*}{ III } & \multirow{3}{*}{ Derajat disosiasi asam basa } & 10 & 92,9 & 4,8 & 0,0 & 2,4 \\
\hline & & 11 & 52,4 & 4,8 & 16,7 & 26,2 \\
\hline & & 12 & 81,0 & 0,0 & 9,5 & 9,5 \\
\hline & Rata-rata konsep III & & 75,43 & 3,2 & 8,7 & 12,7 \\
\hline \multirow{5}{*}{ IV } & \multirow{3}{*}{ Titrasi asam basa } & 13 & 59,5 & 35,7 & 0,0 & 4,8 \\
\hline & & 14 & 50,0 & 45,2 & 2,4 & 2,4 \\
\hline & & 15 & 61,9 & 2,4 & 19,0 & 16,7 \\
\hline & Rata-rata konsep IV & & 57,13 & 27,67 & 7,13 & 7,97 \\
\hline & Rata-rata semua konsep & & 66,5 & 17,5 & 6,0 & 10,0 \\
\hline
\end{tabular}




\section{Analisis Miskonsepsi pada Konsep Utama}

\section{Konsep asam basa dan reaksinya}

Miskonsepsi konsep asam basa dan reaksinya terdiri dari dua sub konsep, yaitu identifikasi asam basa, dan reaksi asam basa.

Miskonsepsi pada konsep identifikasi asam basa yang dialami mahasiswa calon guru kimia adalah pemikiran bahwa zat yang mempunyai atom $\mathrm{H}$ dalam rumus senyawanya jika dilarutkan dalam air akan menghasilkan ion $\mathrm{H}^{+}$dan menyebabkan larutan bersifat asam.

Konsep sebenarnya adalah hanya senyawa yang mempunyai atom $\mathrm{H}$ yang terikat dengan atom yang lebih elektronegatif (misalnya $\mathrm{O}, \mathrm{F}, \mathrm{N}, \mathrm{Cl}$ ) yang akan menghasilkan $\mathrm{H}^{+}$jika dilarutkan dalam air. Atom yang lebih elektronegatif akan menarik pasangan elektron ikatan dengan $\mathrm{H}$ saat ikatan terputus.

Miskonsepsi pada konsep reaksi asam basa yang dialami mahasiswa calon guru kimia adalah pemikiran bahwa reaksi asam basa harus melibatkan ion $\mathrm{H}^{+}$dan $\mathrm{OH}^{-}$dalam suatu reaksi asam basa. Reaksi yang tidak melibatkan ion $\mathrm{H}^{+}$dan $\mathrm{OH}^{-}$ bukanlah reaksi asam basa. Miskonsepsi lainnya adalah bahwa air $\left(\mathrm{H}_{2} \mathrm{O}\right)$ bisa bereaksi dengan asam dan basa karena bersifat netral.

Konsep yang benar dan lebih luas tentang reaksi asam basa diberikan oleh Lewis, yaitu reaksi yang terjadi antara zat yang bersifat basa (penyumbang pasangan elektron bebas) dengan zat yang bersifat asam (penerima pasangan elektron bebas) (Jespersen, dkk., 2012:756). Calon guru kimia sepertinya tidak terbiasa menggunakan defini Lewis dalam konsep asam basa.

Alasan yang menyatakan bahwa zat yang netral bisa bereaksi dengan asam dan basa merupakan hal yang keliru. Hal ini dicontohkan dengan baik oleh garam yang terbentuk dari asam kuat dan basa kuat yang bersifat netral, misalnya $\mathrm{NaCl}$. Garam $\mathrm{NaCl}$ bersifat netral namun tidak bisa bereaksi dengan asam maupun basa. Air $\left(\mathrm{H}_{2} \mathrm{O}\right)$ dapat bereaksi dengan asam maupun basa karena $\mathrm{H}_{2} \mathrm{O}$ bisa menyumbangkan ion $\mathrm{H}^{+}$dan bisa menerima ion $\mathrm{H}^{+}$(Petrucci, dkk., 2011:700-701).

\section{Konsep pH dan perhitungannya}

Miskonsepsi pada konsep $\mathrm{pH}$ yang dialami mahasiswa calon guru kimia adalah pemikiran bahwa $\mathrm{pH}$ larutan netral selalu sama dengan 7. Sebagian mahasiswa berpikiran bahwa $\mathrm{pH}$ netral sama dengan 7 merupakan suatu ketetapan dan tidak berubah pada keadaan apapun. Hal yang serupa juga ditemukan oleh Muchtar \& Harizal (2012:74) pada siswa SMA di kota Medan.

Konsep sebenarnya adalah $\mathrm{pH}$ larutan dipengaruhi oleh temperatur. $\mathrm{pH}$ larutan berubah-ubah menurut fungsi temperatur. Larutan dikatakan netral jika konsentrasi ion $\mathrm{H}^{+}$sama dengan ion $\mathrm{OH}^{-}$. $\mathrm{pH}$ larutan netral sama dengan 7 hanya berlaku pada suhu $25^{\circ} \mathrm{C}$ (Zumdahl \& Zumdahl, 2014:659).

Tidak adanya mahasiswa calon guru kimia yang mengetahui konsep ini dengan benar mengindikasikan bahwa mahasiswa belum mampu menghubungkan konsep asam basa dengan konsep pada kesetimbangan kimia. $\mathrm{pH}$ air murni $\left(\left[\mathrm{H}^{+}\right]\right.$ dalam air murni) dipengaruhi oleh tetapan ionisasi air $\left(\mathrm{K}_{\mathrm{w}}\right)$ yang nilainya berubah tergantung variasi temperatur.

Miskonsepsi pada konsep skala $\mathrm{pH}$ yang dialami oleh mahasiswa calon guru kimia di kota Pekanbaru adalah pemikiran bahwa skala $\mathrm{pH}$ hanya berinterval 0-14. Mereka berpikiran tidak mungkin ada $\mathrm{pH}$ lebih kecil dari nol atau $\mathrm{pH}$ lebih besar dari 14 (Gambar 1[A]).

A
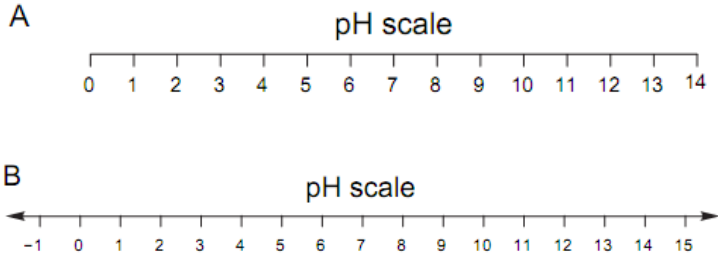

Gambar 1. (A) skala $\mathrm{pH}$ yang tidak benar; (B) skala $\mathrm{pH}$ yang benar

Konsep sebenarnya adalah skala $\mathrm{pH}$ dapat lebih kecil dari nol dan lebih besar dari 14 (Gambar 1[B]). Skala pH harus digambarkan menggunakan tanda panah pada kedua ujungnya. Hal ini berguna untuk menandakan bahwa rentang $\mathrm{pH}$ merupakan suatu interval terbuka bukan tertutup (Lim, 2006:1465). Dalam matematika, rentang tertutup 
dilambangkan tanpa ada tanda panah pada ujung garis skala.

$$
\text { Miskonsepsi pada konsep }
$$

perhitungan $\mathrm{pH}$ yang dialami mahasiswa calon guru kimia adalah pemikiran bahwa larutan $\mathrm{HCl} 1 \times 10^{-8} \mathrm{M}$ mempunyai $\mathrm{pH}=8$. Hal yang sama juga ditemukan oleh Muctar \& Harizal (2012:74). Adapun alasan mahasiswa menyatakan hal ini adalah karena $\mathrm{HCl}$ merupakan asam kuat sehingga terionisasi sempurna, maka $\left[\mathrm{H}^{+}\right]$ akan sama dengan konsentrasi $\mathrm{HCl}$, yaitu $10^{-8}$ M. Dengan mensubstitusikan nilai konsentrasi ini dalam rumus $\mathrm{pH}=-\log$ $\left[\mathrm{H}^{+}\right]$, maka akan didapatkan nilai $\mathrm{pH}=8$. Miskonsepsi lainnya yang ditemukan adalah pemikiran mahasiswa yang menyatakan bahwa tidak mungkin membuat konsentrasi $\mathrm{HCl} 1 \times 10^{-8} \mathrm{M}$.

Konsep sebenarnya adalah $\mathrm{pH}$ larutan $\mathrm{HCl} 1 \times 10^{-8} \mathrm{M}$ kurang dari $7(\mathrm{pH}$ netral) pada suhu $25^{\circ} \mathrm{C}$. Untuk menghitung $\mathrm{pH}$ larutan yang sangat encer (kurang dari $\left.10^{-5} \mathrm{M}\right)$ haruslah melibatkan reaksi kesetimbangan air dalam larutan encer hal ini bisa diabaikan (Jespersen, dkk., 2012:779). Perhitungan $\mathrm{pH}$ larutan $\mathrm{HCl}$ $1 \times 10^{-8} \mathrm{M}$ dapat dilihat pada Gambar 2.

$\mathrm{HCl}$ terionisasi sempurna, jadi $\left[\mathrm{H}^{+}\right]=1 \times 10^{-8} \mathrm{M}$, karena $\left[\mathrm{H}^{+}\right]$dari ionisasi $\mathrm{HCl}$ sangat kecil, maka juga harus diperhitungkan $\left[\mathrm{H}^{+}\right]$dari reaksi autoionisasi air. $\mathrm{K}_{\mathrm{w}}$ air pada $25^{0} \mathrm{C}$ adalah $1 \times 10^{-14}$. Reaksi autoionisasi air

$$
\begin{aligned}
& \begin{array}{llll}
\text { [mula-mula] } & \mathrm{H}_{2} \mathrm{O}_{(\mathrm{l})} & \rightarrow \mathrm{H}^{+} \text {(aq) } & 1 \times 10^{-8}
\end{array}
\end{aligned}
$$

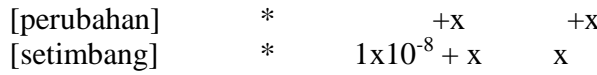

$$
\begin{aligned}
& \mathrm{Kw}=\left[\mathrm{H}_{3} \mathrm{O}^{+}\right][\mathrm{OH}] \\
& =\left(1 \times 10^{-8}+X\right)\left(1 \times 10^{-7}\right)=1 \times 10^{-14} \\
& X=9,512 \times 10^{-8}, \text { maka } \\
& {\left[\mathrm{H}^{+}\right]=1 \times 10^{-8}+9,512 \times 10^{-8} ; \mathbf{p H}=\mathbf{6 , 9 8}}
\end{aligned}
$$

Gambar 2. Perhitungan $\mathrm{pH}$ untuk larutan sangat encer

\section{Konsep derajat disosiasi asam basa}

Miskonsepsi yang dialami oleh calon guru kimia pada konsep ionisasi asam basa adalah pemikiran bahwa asam poliprotik terdisosiasi menghasilkan ion $\mathrm{H}^{+}$ dalam satu tahapan reaksi. Miskonsepsi lainnya adalah hanya asam kuat poliprotik yang terionisasi dalam satu tahapan reaksi, sedangkan asam lemah poliprotik tidak. Hal ini serupa dengan yang ditemukan oleh Lathifa (2018:174) pada siswa SMA di
Kudus berkaitan dengan konsep ionisasi asam poliprotik, seperti $\mathrm{H}_{3} \mathrm{PO}_{4}$.

Konsep yang sebenarnya adalah asam poliprotik, baik asam kuat maupun asam lemah terionisasi secara bertahap melalui beberapa tahapan reaksi ionisasi (Jespersen, dkk., 2012:780).

Miskonsepsi pada konsep kesetimbangan reaksi autoionisasi air adalah pemikiran bahwa nilai tetapan kesetimbangan air $\left(\mathrm{K}_{\mathrm{w}}\right)$ selalu sama dengan $1 \times 10^{-14}$ pada keadaan apa pun. Sebagian mahasiswa beranggapan nilai ini merupakan suatu tetapan yang disepakati dan bukan hasil eksperimen.

Konsep yang sebenarnya adalah bahwa nilai tetapan kesetimbangan air $(\mathrm{Kw})$ dipengaruhi oleh temperatur dan ini ditentukan secara eksperimen. Nilai tetapan ketimbangan air pada suhu $25^{\circ} \mathrm{C}$ adalah $1 \times 10^{-14}$. Nilai $\mathrm{Kw}$ akan berubah menurut fungsi temperatur Zumdahl \& Zumdahl, 2014:659). Miskonsepsi yang terjadi dapat disebabkan oleh mahasiswa calon guru kimia terbiasa menggunakan nilai $\mathrm{Kw}=1 \times 10^{-14}$ dalam perhitungan sehingga mereka menganggap ini merupakan suatu tetapan.

\section{Konsep titrasi dan indikator}

Miskonsepsi yang dialami oleh calon guru pada konsep titrasi asam basa adalah pemikiran bahwa $\mathrm{pH}$ pada titik ekivalen bergantung pada indikator yang digunakan dalam titrasi. Beberapa mahasiswa juga berpikiran bahwa $\mathrm{pH}$ pada titik ekivalen selalu sama dengan 7 . Konsep yang sebenarnya adalah bahwa $\mathrm{pH}$ pada titik ekivalen bergantung pada jenis asam basa yang digunakan dalam titrasi. Titik ekivalen titrasi asam kuat dengan basa kuat adalah 7 . Titik ekivalen titrasi asam lemah dengan basa kuat lebih besar dari 7, sedangkan titrasi basa lemah dengan asam kuat lebih kecil dari 7 (Secken, 2010:240-242). Sedangkan Widarti, dkk., (2017:2-5) menemukan bahwa miskonsepsi pada titrasi terjadi sebagian besar pada kemampuan simbol, makroskopik, dan perhitungan titrasi.

Miskonsepsi pada konsep indikator titrasi asam basa adalah pemikiran bahwa indikator pada titrasi asam basa berguna untuk menandai bahwa asam dan basa tepat habis bereaksi. Konsep yang sebenarnya adalah bahwa indikator pada 
titrasi asam basa berguna untuk menandai titik akhir titrasi bukan untuk menandai asam basa tepat habis bereaksi. Titik akhir tercapai saat titik ekivalen reaksi terlampaui dengan penambahan sedikit volume peniter.

\section{Simpulan dan Saran}

Simpulan

Berdasarkan penelitian dan analisis yang telah dilakukan, maka dapat disimpulkan bahwa miskonsepsi tertinggi calon guru kimia terjadi pada sub konsep $\mathrm{pH}$ dan perhitungannya. Oleh karena itu, diharapkan kepada pendidik agar lebih memperhatikan konsep dan perhitungan $\mathrm{pH}$ terhadap anak didiknya.

Saran

Diperlukan suatu penelitian lanjutan yang bertujuan untuk mengetahui penyebab atau sumber miskonsepsi calon guru kimia dan cara mengatasinya sehingga miskonsepsi dapat dicegah.

\section{Daftar Pustaka}

Ikenna, I.A. (2014). Remedying Students' Misconception in Learning Chemical Bonding and Spontaneity through Intervension Discussion Learning Model (IDLM). International Scholarly and Scientific Research \& Innovation, 8(10):3259-3262.

Irwansyah, Sukarmin \& Harjana. (2018). Development of Three-Tier Diagnostic Instruments on Students Misconception tes in fluid concept. Jurnal Ilmiah Pendidikan Fisika Al-BiRuNi, 07(2):207-217

Jespersen, N.D., Brady, J.E. \& Hyslop Alison. (2012). Chemistry: the molecular nature of matter $\left(6^{\text {th }}\right.$ ed). USA : John Wiley \& Sons .

Kurniawan, Y. \& Suhandi, A. (2015). The Three-Tier Test for Identification The Quantity of Students' Misconception on Newton's First Laws. GTAR-2015 Full Proceeding (2): 313-319.
Lathifa, U. (2018). Correcting students misconception in acid and base concept using pdeode instruction strategy. Unnes Science Education Journal. 7(2):170-177.

Lim, K.F. (2006). Negative pH does exist. Journal of Chemical Education, 83(10):1465.

Muchtar, Z. \& Hasrizal. (2012). Analyzing of Students' Misconceptions on AcidBase Chemistry at Senior High Schools in Medan. Journal of Education and Practice. 3(15):65-74.

Noviartati, K. (2015). Profil Keterampilan Mengajar Mahasiswa Calon Guru Melalui Kegiatan Induksi Guru Senior. Jurnal Riset Pendidikan 1(1):57-64.

Petrucci, R.H., Herring, F.G., Madura, J.D., \& Bissonnette. (2011). General Chemistry : Principles and Modern Applications $\left(10^{\text {th }}\right.$ Ed). Toronto : Pearson Canada Inc.

Resbiantoro, G., dan Nugraha, A.W. (2017). Miskonsepsi Mahasiswa Pada Konsep Dasar Gaya dan Gerak untuk Sekolah Dasar. Jurnal Pendidikan Sains (JPS), 5 (2):80-87

Sadhu, S., Tima, M.T., Cahyani, V.P., Laka, A.F., Annisa D., dan Fahriyah, R. (2017). Analysis of acid-base misconceptions using modified certainty of response index (CRI) and diagnostic interview for different student levels cognitive. Int. J. Sci. Appl. Sci.: Conf. Ser. 1(2):91-100.

Secken, N. (2010). Identifying students' misconception about Salts. Procedia Social and Behavioral Sciences 2: 234-245.

Supartini, E. (2003). Peran Guru Dalam Pembaharuan Pendidikan. Dinamika Pendidikan No.1/Tahun X.

Suparno, P. (2013). Miskonsepsi dan Perubahan Konsep Dalam Pendidikan Fisika. Jakarta: PT. Grasindo.

Yulita, I., (2018). Analisis Prekonsepsi Siswa TerhadapKemampuan Menghubungkan Konteks Air Laut Dengan Konten Hakikat Ilmu Kimia Kelas X SMA. 
Jurnal Pendidikan Sains (JPS), 6(1):64-72.

Widarti, H.R., Permanasari, A., dan Mulyani, S. (2017). Students' Misconceptions on Titration. J. Phys.: Conf. Ser. 812 012016:1-6. doi:10.1088/17426596/812/1/012016

Wulandari, C., Susilaningsih, E., \& Kasmui. (2018). Estimasi Validitas dan Respon Siswa Terhadap Bahan Ajar Multi Representasi : Definitif, Makroskopis, Simbolik pada Materi Asam Basa. Jurnal Phenomenon, 8(2):165-167.

Zumdahl, S.S. \& Zumdahl, S.A. (2014). Chemistry (9 Ed). Belmont: Brooks / Cole. 